Florida International University FIU Digital Commons

$12-1983$

\title{
Discretionary salt consumption in airline food service : a feasibility study
}

Kathleen E. Dierkes

Florida International University

DOI: $10.25148 /$ etd.FI14062290

Follow this and additional works at: https://digitalcommons.fiu.edu/etd

Part of the Dietetics and Clinical Nutrition Commons

\section{Recommended Citation}

Dierkes, Kathleen E., "Discretionary salt consumption in airline food service : a feasibility study" (1983). FIU Electronic Theses and Dissertations. 2818.

https://digitalcommons.fiu.edu/etd/2818

This work is brought to you for free and open access by the University Graduate School at FIU Digital Commons. It has been accepted for inclusion in FIU Electronic Theses and Dissertations by an authorized administrator of FIU Digital Commons. For more information, please contact dcc@fiu.edu. 


\section{DISCRETIONARY SALT CONSUMPTION IN AIRLINE}

FOOD SERVICE: A FEASIBIIITY STUDY

by

Kathleen E. Dierkes

Studies have estimated total daily salt consumption in the U.S. at 10 - 14.5 grams, despite increasing public awareness and decreased usage by the food industry. To avoid excess governmental regulation to modify current salt intake, determination of the amount of salt currently being used in a discretionary manner is needed.

This study investigated the feasibility/limitations of a data collection technique to assess discretionary salt intake in in-flight meal service. Discretionary salt use by airline passengers was determined by weighing salt packets remaining on used meal trays. Results showed an average discretionary salt consumption of $167 \mathrm{milligrams} / \mathrm{meal}$ among passengers able to add up to one gram of salt to their meal. At least $63 \%$ of the passengers used no discretionary salt. Intake was not influenced by sodium content of the menu, different flight days, or inclusion of a salad with the meal. Salt usage appeared to be an "indescriminate" function of habit.

The data collection tool proved a feasible method for estimating discretionary salt intake and could be useful in future consumer education studies. 
FLORIDA INTERNATIONAL UNIVERSITY

DEPARTMENT OF DIETETICS AND NUTRITION

\section{DISCRETIONARY SALT CONSUMPTION \\ IN AIRLINE FOOD SERVICE,}

A FEASIBILITY STUDY

A Thesis submitted to

The Department of Dietetics and Nutrition

in partial fulfillment of the requirements for the degree of Master of Science in Dietetics

By

Kathleen E. Dierkes

Miami, Florida

December, 1983 
A thesis submitted to the Department of Dietetics and Nutrition in partial fulfillment of the requirements for the degree of Master of Science

Discretionary Salt Consumption in Airline Food Service: A Feasibility Study

Kathleen E. Dierkes

Approved:

Sharon Wallace

Visiting Assistant Professor of Dietetics and Nutrition Chair of Thesis Committee
Robert C. Fisher Acting Dean of the College of Technology
Nancy S. Wellman

Asscciate Professor of

Dietetics and Nutrition
Benigno T. Alvarez

Adjunct Instructor of

Mathematical Science 
List of Tabies

List of Appendices

CHAPTER

I. Introduction 1

Statement of the Problem 1

Hypotheses 3

Definition of Terms 3

II. Review of the Literature 4

What is Table Salt 4

Salt Intake and Relationship to Hypertension 5

Population Studies of Salt Intake and 6 Hypertension

Estimates of Salt Intake 7

Recent Estimates of Total Daily salt Intake 8

Recent Estimates of Non-Discretionary Salt 10 Intake

Recent Estimates of Discretionary Salt Intake 11 Influences on Salt Intake 14 Public Awareness/Policy Issues 1.5 Consumer Education 18

Monitoring Changes in Salt Consumption 18

References 20

III. Conduct of the Study 25

Study Objectives $\quad 25$

The Setting 25

Description of subjects 26

Data Collection $\quad 27$

Analysis of Data 30

References $\quad 32$

IV. Results and Discussion 33

References $\quad 48$

V. Summary, Conclusions, and Recommendations 49

VI. Appendices $\quad 52$

VII. Bibliography 59 


\section{LIST OF TABLES}

Page

1. Sources of Dietary Sodium and Estimates Total Sodium Intake

2. Percent of Passengers Selecting Alternate Menu Choices

3. Weights of Salt Packets Left on Airline Meal Trays

4. Laboratory Sodium Assay Versus Sodium Content Estimate From Food Composition Tables for Entree Items

5. Airline Passengers in Each Defined Category of Table Salt Use

6. Average Table Salt Use on Different Flight Dates

7. Table Salt Use by Airline Passengers Who Selected Different Entrees

8. Average Table Salt Used by Airline Passengers Consuming Different Amounts of Entree and Salad

9. Comparison of Table Salt Consumption Figures with Other Studies

FIGURE

1. Comparison of Table Salt Use by Airline Passengers Selecting Different Meal Entrees 
1. Table Salt Collection Talley Sheet A

2. Laboratory Procedures: Sodium Chloride Assay B

3. Laboratory Analysis: Titrations C

4. Estimates of Sodium Content of Inflight meals by Laboratory Assay

5. "Book Estimates" of Sodium Content of Inflight Meals 
CHAPTER I

INTRODUCTION

\section{STATEMENT OF THE PROBLEM}

Dietary sodium consumption has become a concern to the health professional $1,2,3$ and has received a great deal of attention from the news media, ${ }^{4}$ popular press, ${ }^{5}$ regulatory agencies, ${ }^{6}$ and congress. ${ }^{7}$ It has been suggested that both hypertensive and normotensive persons would benefit by a reduction in sodium intake. Specifically, Fries has suggested that a decrease in dietary sodium intake to less than forty-five milliequivelant (Meg) per person ( 1000 $\mathrm{mg} \mathrm{Na}, \sim 2.5 \mathrm{~g}$ salt per day) would elininate essential hypertension as a major health problem. ${ }^{8}$ A large body of evidence exists to support this view. $9,10,11$ However, not all medical authorities agreee that a nationwide policy of salt restriction would be beneficial. 12

A recent governmental report estimated the current average salt consumption to be ten to twelve grams daily, ${ }^{14}$ which represents twenty times the estimated minimum need.

The possibility that such an excessive chronic ingestion of sodium may have adverse health effects has inspired a drive to increase public awareness of high salt use. 15 However, consumption figures reported by Bowen, 16 Meneely and Battarbee, ${ }^{17}$ Dickonson, 18 and Shank, ${ }^{19}$ indicate 
that American salt consumption has not decreased despite increasing public awareness and despite reported decreased use of salt by the food industry. If excessive dovernmental regulation of food industry salt use is to be avoided (regulation has already begun on a voluntary basis), it is necessary to determine the amount of salt currently being used in a discretionary manner and to identify appropriate media for effective public and professional education.

In this paper, a new methodology for determining discretionary sodium intake will be investigated for its feasibility as a data collecting tool. Estimation of discretionary salt use by airline passengers will be determine by weighing salt packets from meal trays. 


\section{HYPOTHESES}

1. The technique of observing returned airline meal trays will, with acceptable efficiency, yield a measure of discretionary salt use by airline passengers.

2. There is no significant difference in salt consumption between airline passengers receiving different inflight meals.

3. There is no significant difference between the salt consumption of those airline passengers who consume salad, compared to those who consume no salad.

4. There is no significant difference between salt consumption on a particular flight occuring on different days of the week.

5. Assayed sodium content of airline meals will not differ from estimations derived from standard tables.

\section{DEFINITION OF TERMS}

Table Salt

In this study, use of an approximate one gram salt packet (included in a pre-packaged "tray pack" with other condiments and serving utensils) was used to evaluate discretionary salt consumption by the airline passengers. $\underline{\text { Salt }}$

In this paper, the term "salt" refers to sodium chloride: 1) One gram of sodium chloride is approximately 400 millgrams of sodium, 2) one gram of sodium chloride is seventeen milliequivalents of sodium. 
CHAPTER II

REVIEW OF THE LITERATURE

\section{WHAT IS TABLE SALT}

Chemically, table salt contains forty percent sodium and sixty percent chloride, with a minor admixture of other inorganic chemicals, several of nutritive value, such as iodine. Salt has the following usages/functions: a flavor enhancer (condiment), a curative/preservative, and an industrial ore (i.e., glass making). In ancient times it was used as a "medicine", a religious symbol, and a determinant of social status. 20

The thing we don't know with precision that we wish we did know is if there is an "ideal level" of sodium intake for a population.21

According to F.D.A.'s Dr. Alan Forbes, even though the optimum level of sodium intake has not been established, it is known that sodium is essential for normal growth and health maintenance. Sodium is involved with carbohydrate metabolism, is an integral part of the acid/base balance mechanism, is needed for maintenance of electrical activity of all cells, and in the regulation of extra cellular fluid volume. The sodium requirement for growth and replacement of unavoidable daily losses from skin and feces is 100 to 200 milligrams daily (250-500 milligrams salt.) ${ }^{22}$ 
Salt appetite is acquired/learned rather than inherited and appears to change with development (age). ${ }^{22}$ salt appetite and sodium intake seems to be controlled mostly through taste receptors. 23,24 Although salt consumption increases when one is sodium deficient (in need), little is known about the physiologic basis for this phenomenon. The phenomenon is complex, as humans with sufficient sodium stores (non-need) will continue to take large quantities of salt. Recent studies have shown that decrease in salt intake is followed by changes in salt preference. ${ }^{25}$ It takes approximately two to three months after a decrease in salt intake to modify taste preference and intensity judgments of saltiness. As salty foods become more common in the national food supply, the preferred level of salt in food is thought to increase, even by the developing infant. Today, as mentioned, the average salt intake is twenty times the nutritional requirement.

\section{SALT INTAKE AND HYPERTENSION}

Although the mechanism of essential hypertension (increased extracellular fluid, increased blood pressure) is still obscure, the evidence is very good, if not conclusive, that reduction of dietary salt to below two grams daily would result in prevention of hypertension and its dis-
appearance as a major health problem. 26

Increased extracellular fluid volume is the most significant factor in initiating the sequence of events leading to chronic hypertension. Low sodium diets reduce 
fluid volume and thus are contributory to reducing blood pressure. In studies by Fries, and Dahl and Love, sodium restriction to 200 milligrams daily had a positive effect on reducing blood pressure in mild hypertensive patients. 26,27 Wilber reported that even though dietary sodium'has not been demonstrated as a primary cause of hypertension, recent studies of diet modification on fluid retention do demonstrate (consistent with Fries and Dahl) that sodium restriction is an effective therapeutic tool in controlling hypertension. 28

Not all hypertension authorities support the view that dietary sodium intake is primarily, or even partially responsible for the development of essential hypertension. 29 Both the F.D.A. and the American Academy of Pediatrics state that it has not been conclusively established that salt consumption is a major factor in the onset of hypertension in human beings, but recent studies suggest an association between high sodium intake and the prevalence of hypertension. 30,31

\section{POPULATION STUDIES OF SALT INTAKE AND HYPERTENSION}

Even though the relationship between salt intake and the development of hypertension has been emphasized in earlier literature, ${ }^{32}$ the cause and effect hypothesis has not been confirmed. According to F.D.A.'s Dr. Lecos,

Although interpopulation studies suggest an association between high sodium intake and the onset of hypertension, it has not been conclusively established that sodium consumption is a major factor in its cause. ${ }^{33}$

A correlation exists between the dietary habits of 
different societies and the incidence of hypertension. Meneely and Dahl estimated the sodium chloride intake of several populations on the basis of twenty-four hour urine collections: twenty Alaskan Eskimos consumed an average of four grams of salt daily with no evidence of hypertension; 235 Marshall Islanders consumed an average of seven grams daily with 6.9 percent hypertension; 1,124 U.S. males consumed an average of ten grams daily and had a prevalence of 8.6 percent hypertension; and two groups of Japanese totaling averaged 14 to 26 grams daily with a prevalence several fold higher than in the U.S. group. The investigators propnsed that chronic escess consumption of salt may play a primary role in the pathogenesis of hypertension in "responsive" individuals. Evaluation of population studies turns on assessment of the validity of intake data.

\section{ESTIMATES OF SALT INTAKE}

Contribution to daily salt intake comes from drugs, drinking water, natural salt content of foods, salt added in food processing, discretionary use of salt (table salt), and addition of salt to foods in cooking. Both Fregly and the Select Committee on GRAS substance (SCOGS) reported that the estimated salt intake is derived from the following three sources; one-third from processed foods, one third from natural sources and the remaining third from discretionary addition of salt to food. 35,36

The most recent review of estimates of salt intake reported by Fregly (1983) indicated an average daily intake 
of sodium chloride in the U.S. (discretionary and nondiscretionary) ranging from 10 to 14.5 grams. 35 scoGs reported a narrower range of average daily salt intake between 10 and 12 grams. ${ }^{36}$ (See table 1). ScoGs made the following statement in regard to salt intake estimates:

Given the diversity of the data and the range of individual intakes, these estimates are considered very rough approximations of the national average. The best estimation of sodium intakes based on these data, expressed as sodium 36 chloride, is not less than 10 to 12 grams.

Other earlier studies have reported conflicting data due to methodology utilized. The following are estimations by previous studies:

1. Dahl Studies (1961): 10 grams/day 37

2. Grollman Study (1961): 10-15 grams/day 38

3. Framingham Study (1962): 6-12 grams/day 39

4. Ahrens and Boucher, "Simulated American Diet" Study (1978): 5 grams/day 40

The following different methods have been utilized to assess salt intake: dietary interview, twenty-four hour urine samples, estimation of table salt intake, long term observations of a population's cooking and eating practices, survey (salt habit questionnaire), direct food analysis, per capita disappearance of snack foods, and per capita disappearance of salt use in food processing. 41

\section{RECENT ESTIMATES OF TOTAL DAILY SALT INTAKE}

There are several intrapopulation studies of salt intake in the U.S. based on various data from dietary and industry 
surveys, sodium excretion data, direct food analysis, and production sales reports. 42 (See Table 1) Results of these investigations, organized by the mode of data collection can be summarized as follows:

\section{Excretion Data}

Altman and Dittmer (1974):

9 grams total salt intake/day ${ }^{42}$ Mickelson (1977):

14 grams total salt intake/day 43

$$
\text { Direct Food Analysis Data. }
$$

F.D.A. selected minerals-in-food survey or market basket collections $^{44}$ (1976):

17.1 grams total salt intake/day

F.D.A. total diet studies $(1977-1980)^{45}$ :

$1.8-2.2$ grams/day for infants

$4.0-4.5$ grams/day for toddlers

$16.7-17.3$ grams/day for adults

\section{Industrial Surveys}

Bowens, Bureau of Mines data $(1966-1970)^{47}$ :

$$
14.5 \text { grams/day }
$$




\section{Dietary Survey}

1. Tuthill and Callabrese (1981) 48 :

$$
\begin{gathered}
7.1-7.3 \text { grams/day for children in high } \\
\text { sodium water community } \\
6.3-6.4 \text { grams/day for children in low } \\
\text { sodium water community }
\end{gathered}
$$

2. Mickelson $(1977)^{43}$ :

$$
\text { 14. } 0 \text { grams/day }
$$

\section{RECENT ESTIMATES OF NON-DISCRETIONARY SALT INTAKE}

Total daily non-discretionary intake,

range from 4.5 to 12.6 grams per day. 49 sodium chloride ingested with grain and cereal products and meat comprise fifty percent of daily non-discretionary sodium chloriae intake. (See Table 1). Results of investigations organized by mode of data collection:

\section{Direct Food Analysis Data}

1. F.D.A. Market Basket Collections (1976, 1977, 1978, 1980 surveys) ${ }^{50}$ :

$$
11.8-12.6 \text { grams/day }
$$

2. N.R.C. Survey $(1970)^{45}$ :

7. 1 grams/day

$$
\begin{gathered}
\frac{\text { Industrial Survey }}{\text { N.R.C. Survey }(1970 \text { and } 1977)^{46}:} \\
1970-11.0 \text { grams per capita/day } \\
1977-8.2 \text { grams per capita/day }
\end{gathered}
$$


Bowen, Bureau of Mines data $(1966-1970)^{47}$ :

$$
8.0 \text { grams/day }
$$

$$
\begin{aligned}
& \text { Mickelson }(1977)^{43} \text { : } \\
& 9.7 \text { grams/day }
\end{aligned}
$$

\section{RECENT ESTIMATES OF DISCRETIONARY SALT INTAKE}

Studies dealing specifically with discretionary sodium intake are few. According to Fregly this is due to the difficulties in framing adequate study designs. 35

Estimates of discretionary salt intake reported range from 3 to 6.5 grams per day. ${ }^{50,51}$ (See Table 1) Organized by mode of data collection:

$$
\text { Direct Food Analysis Data }
$$

1. F.D.A. Market Basket Collections $(1976)^{52}$ :

$$
4.6 \text { grams/day }
$$

2. F.D.A. Market Basket Collections (1977, 1978, 1980)

4.5 grams/day

$$
\text { Production and Sales Date }
$$

1. Wood, Retail Sales (1970) ${ }^{54}$ :

$$
3.42 \text { grams/day }
$$

2. Bowen, Bureau of Mines Data $(1966-70)^{47}$ :

$$
6.5 \text { grams/day }
$$

3. Dickonson $(1980)^{55}$ :

$$
\text { 8.9 grams per capita/day }
$$




\section{Mickelson $(1977)^{43}$ : \\ 5.6 grams/day}

In summary, estimates of total daily salt intake range from 6.3 to 17.3 grams; estimates of non-discretionary daily salt intake range from 4.6 to 12.6 grams; and discretionary daily salt intake estimates range from 3.4 to 6.5 grams. 11 The large range of estimates may be due to the variety of data collection techniques utilized and the different time frames in which the studies were conducted. 
Dietary Sources

Naturally Occurring in foods

Sodium Intake

Study Reference ( $\mathrm{gNaCl} / \mathrm{d}$.

$2.5-4.5$

3.0

Added by Industrial

Processing

$$
\begin{aligned}
& 7.1 \\
& 8.0 \\
& 9.0-9.5 \\
& 9.7
\end{aligned}
$$

Total Non-Discretionary $\mathrm{NaCl}$ Intake

$$
\begin{aligned}
& 11.8-12.6 \\
& 4.6-6.3
\end{aligned}
$$

Discretionary Addition by the Consumer

3.4

6.5

4.6

4.5

5.6

Total Dietary $\mathrm{NaCl}$
10.0

14.5

7.1

17.1

$16.7-17.3$

$7.1-7.3$

$6.3-6.4$

14.0

$8-10$
66-70 Bowen-Production Sales Data

1976 F.D.A. Direct

Food Analysis

1970 N.R.C.- Industry Survey

1966-70 Bowen

1976 F.D.A.

1977 Mickelson-Diet Survey

$1976,1977,1978,1980$ F.D.A.

1971-74 Hanes I Survey

1970 Wood-Retail

Sales

66-70 Bowen

1976 F.D.A.

$1977,1978,1980$

F.D.A.

1977 Mickelson

1961 Dahl-Excretion

Data

66-70 Bowen

1970 N.R.C.

1976 F.D.A.

1977, 1978, 1980 F.D.F.

1981 Tuthill \&

Calabrese-Diet Survey

1981 Tuthill \&

Calabrese

1977 Mickelson

1980 Dickorson 
Fregly reported three major influences on non-discretionary salt intake: age, sex, and food consumption patterns of the individual. 56

\section{AGE AND SEX}

Abraham reported the mean daily non-discretionary intake of sodium chloride for males, ages 1 to 74 years, was approximately 6.3 grams. The maximum intake occurred from 18 to 44 years. Females were reported to have a lower nondiscretionary salt intake, with an average of 4.6 grams. The maximum daily intakes occurred between 6 to 11 years. 57

\section{FOOD CONSUMPTION PATTERNS}

Investigators reported that frequency of food group eaten on a daily basis is the most potent influence on total salt intake. $58,59,60$

The greatest amount of sodium chloride added by food processors was in the categories of baked goods, breakfast cereals, and grain products. The second largest contribution was in the category of mixed protein, meat, fish, and poultry. The third major source was from milk and milk products.

These three categories are the largest contributors to total daily intake and require special consideration in attempts to reduce sodium intake.

Fregly reported that although a number of factors are now known to influence non-discretionary salt intake, the influences of discretionary salt intake are still to be determined. 61 


\section{Hypertension Debate}

SCOGS reported to the F.D.A. that it was the prevalent judgement of the scientific community that consumption of sodium chloride be lowered in the U.S.

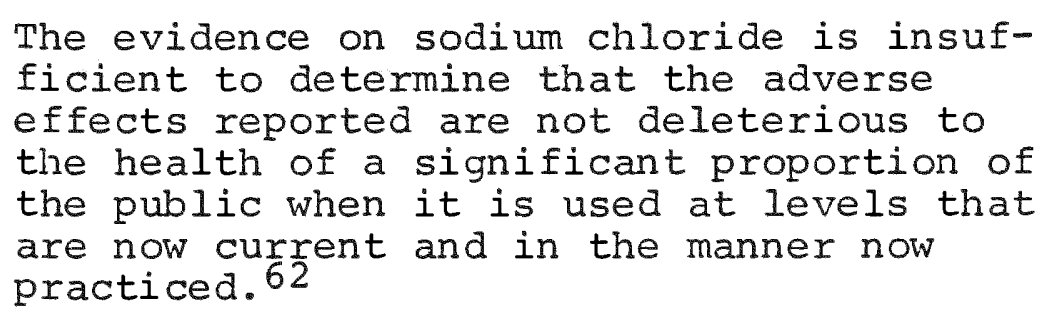

The proposal of the nationwide policy of salt restriction appears to be based on the hypertension hypothesis. It is postulated that a nationwide moderate reduction in salt intake would:

1. Prevent high blood pressure in some proportion of the general population.

2. Control hypertension in those already hypertensive.

3. Do no harm, even if it were not beneficial. 63

Furthermore, the select Committee favored the development of guidelines for restricting the amount of salt labeling on foods. The Select committee conclusives are similar to sentiments of other governmental and medical organizations. 64,65

In contrast, Laragh and Pecker strongly oppose the nationwide public health policy of salt restriction. The researchers stated it is premature to make any definitive recommendation of moderate salt restriction until there is conclusive data. Furthermore, the idea that moderate reduction in dietary salt throughout our society would be harmless is unproved. The argument against a nationwide anti-salt policy is based on 
the following: 63

1. No studies have been conducted that support the recommendation that moderate or drastic reduction of dietary salt consumption could prevent hypertension.

2. There is not a large body of evidence that restriction of dietary salt would help most persons who already have hypertension.

3. There is no proof that indiscriminate reduction of dietary salt would not do any harm. Lowering salt intake would mean decreased use of foods such as bakery goods and dairy products which could in turn decrease intake of essential nutrients.

Speculative reasoning, however appealing should not be a basis for a major change in public health policy and could intrude in many ways on quality of life. Public health policy should be decided by facts, not by hopes or opinions.

\section{Effecting Change}

Public awareness of the possible harmful effects of excess salt in the diet gained impetus in 1970 when baby food manufacturers moved towards elimination of salt added to their products. By 1977, addition of salt to all infant foods was discontinued by manufacturers. 66

In 1977, the dietary goals for the United States included a reduction in salt intake. ${ }^{67}$ The U.S. dietary guidelines were then developed which supported the nationwide anti-salt policy. 68

A 1980 F.D.A. survey of 1,500 shoppers revealed that 
American consumers were aware of the harmful effects of the salt consumption due to the recent widespread publicity. Results showed that $68 \%$ were trying to reduce salt intake. 69 A trend in increased consumer awareness responding to adverse publicity on salt consumption was also reported by Filer. ${ }^{66}$ Per capita disappearance of salt used in food processing from 1970 to 1978 decreased from 10.9 to 8.4 grams per day. A recent F.D.A. survey showed the number of food packages displaying sodium information has increased between 1977 and 1979, from 7.5 to 13.4 percent of the dollar value of foods sold. It can be concluded that some of the food manufacturers are vigorously engaging in voluntary sodium labeling. However, only six percent of 1,031 national brands that list sodium containing ingredients, state the actuai amount. ${ }^{69}$ contrary to the F.D.A. conclusion, The Center For Science in the Public Interest (C.S.P.I.) reported that the food manufacturers were resisting pressure to identify the salt content of foods.

It is F.D.A. policy to encourage health professionals to urge modification of salt intake for the general public and to encourage increased sodium labeling on food. 71 In March 1981, the F.D.A. announced a five point plan in persuance of increased regulatory initiatives concerning sodium. It includes the following:

1. Reduction of sodium content in processed foods. 2. Mandatory sodium labeling.

3. Continuation of the total diet study to detect trends 
in salt consumption.

4. Research to investigate consumer perception, knowledge and purchasing practices related to sodium and hypertension.

5. Public education programs.

\section{CONSUMER EDUCATION}

The recently proposed F.D.A. plan concerning salt restriction cannot succeed without consumer education. Educating the consumer about sodium will require more than including sodium information on packages; government and industry should aim to explain what sodium is, where it is found in the diet, and how sodium labeling can be used. Hunt suggested that educational programs can help avoid the need for excessive governmental regulation for sodium content of prepared and processed foods. 72

\section{MONITORING CHANGES IN SALT CONSUMPTION}

Continuation of the F.D.A. total diet analysis program will identify trends in salt consumption. However, it cannot accurately measure the effectiveness of educational programs conducted by the food industry; by the medical profession, or by other nutrition educators. Thus, it is the opinion of various investigators that dietary intake studies concurrent with nutrition education efforts monitored over a period of years will be needed to target the consumer education effort. 73

It is concluded that new techniques are needed for use in studies of consumer awareness and consumer salting practices. 
We need to learn other ways to reduce sodium content in the American diet. such as through public and professional education, and voluntary efforts such as labeling of canned and packaged food. 


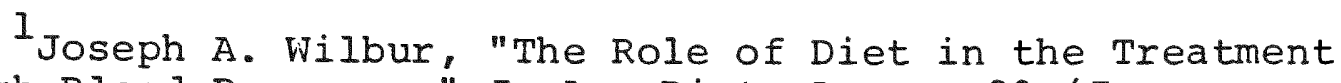
of High Blood Pressure," J. Am. Diet. Assoc. 80 (January 1982): 25 .

2Friedrich C. Iuft, "Sodium Restriction in the Treatment of Hypertension," Cardiovascular Diseases 7(10) (October 1981): 15 .

${ }^{3}$ Committee on Nutrition, American Academy of Pediatrics, "Salt Intake and Eating Patterns of Infants and Children in Relation to Blood Pressure," Pediatrics 54 (January 1974):115.

${ }^{4}$ C. Wallis, "Salt: A New Villain?," Time 119 (1982):64.

${ }^{5}$ Gina Kolata, "Value of Low Sodium Diets questioned," Science 216 (April 1982): 38 .

${ }^{6}$ Fred R. Shank, et al. "Perspective of Food and Drug Administration on Dietary Sodium," J.Am. Diet. Assoc. 80 (January 1982): 29.

7"A Current Perspective on the Sodium Issue," Nutrition Policy Issues 10 (April 1982): 1 .

${ }^{8}$ Edward D. Fries, "Salt Volume and the Prevention of Hypertension," Circulation 53 (1976): 589.

${ }^{9}$ Ambard, L. and E. Beaujard, "Causes De L'Hypertension Arterielle," Arch. Gen. Med. I (1904):520.

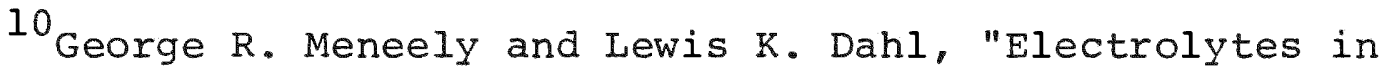
Hypertension: The Effects of Sodium Chloride. Evidence from Animal and Human Studies," Med. Clin. North Am. 45 (1961):27.

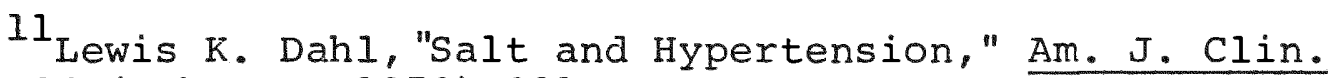
Nutr. 25 (February 1972): 231.

12 John Laragh and Mark Pecker, "Dietary Sodium and Essential Hypertension: Some Myths, Hopes and Truths," Ann. Intern. Med. 98 (2) (May 1983):735.

13 Melvin J. Fregly, "Estimates of Sodium and Potassium Intake," Ann. Intern. Med. 98 (May 1983): 735.

${ }^{14}$ Select Committee on Gras Substances, Evaluation of Health Aspects of Sodium Chloride and Potassium Chloride as Food Ingredients (Bethesda, Maryland: Life Sciences Research office, Federation of Anerican Societies for Experimental Biology, 1979), pp. 1-62. 


\section{p. 792 . \\ ${ }^{15}$ Fregly, "Estimates of Sodium and Potassium Intake,"}

${ }^{16}$ R. E. Bowen, E. J. Reid and R. J. Moshy, "Designing Formulated Food for the Cardiac Concerned," Prev. Med. 2 (1973): 366 .

17 George R. Meneely and Harold D. Battarbee. "Sodium and Potassium," Nutr. Rev. 34 (August 1976):325.

${ }^{18}$ William E. Dickonson, "Salt Sources and Markets," in Biological and Behavioral Aspects of Salt Intake, eds. Morley R. Kare, Melvin J. Fregly, and R.A. Bernard (New York: Academic Press, 1980), pp. 49-50.

${ }^{19}$ Shank et al., "Perspectives on Dietary Sodium," p. 29. ${ }^{20}$ Richard H. Forsythe and R. A. Miller, "Salt in Processed Foods," in Biological and Behavioral Aspects of Salt Intake, eds Morely R. Kare, Melvin J. Fregly, and R.A. Bernard (New York: Academic Press, 1980), p. 221.

${ }^{21}$ Roger $W$. Miller, "The Case for Moderating sodium Salt Consumption," The F.D.A. Consumer (October 1981): 4 .

${ }^{22}$ Meneely and Battarbee, "Sodium and Potassium," p. 225.

${ }^{23}$ Gary K. Beauchamp, Mary Bertino, and Karl Engelman, "Modification of Salt Taste," Ann. Intern. Med. 98 (2) (May 1983) : 763 .

24 Meneely and Battarbee, "Sodium and Potassium," p. 225. ${ }^{25}$ Beauchamp et al., "Modification of Salt Taste," p. 763. ${ }^{26}$ Fries, "Salt Volume and Prevention," p. 589.

27 Lewis K. Dahl and R. A. Love, "Etiological Role of Sodium Chloride Intake in Essential Hypertension in Humans," JAMA. 1964 (1957): 397.

${ }^{28}$ Wilber, "Role of Diet in High Blood Pressure," p. 25. 29 Laragh and Pecker, "Dietary Sodium: Some Myths," p. 735 .

${ }^{30}$ Chris Lecos, "Tips for the Salt Conscious Consumer," The F.D.A. Consumer (November 1981): 27 .

${ }^{31}$ Committee on Nutrition, American Academy of Pediatrics, "Salt Intake of Infants," p. 115. 
${ }^{32}$ Thomas R. Dawber et al. "Environmental Factors in Hypertension," in Epidemeology of Hypertension, eds. J. Stamler, R. Stamler, and T. Pullman (New York: Grune and Stratton, 1967), pp. 245-251.

${ }^{33}$ Lecos, "Tips for the Consumer," p. 27.

${ }^{34}$ Meneely and Dahl, "Electrolytes in Hypertension," p. 271 .

p. 792 .

${ }^{35}$ Fregly, "Estimates of Sodium and Potassium Intake,"

${ }^{36}$ SCOGS, Evaluation of the Health Aspects of Sodium Chloride, p. $3 \overline{5}$.

37 Meneely and Dahl, "Électrolytes in Hypertension," p. 532 .

38 Arthur Grollman, "Metabolic Observations in Essential Hypertension," Postgrad. Med. 33 (June 1963):532.

${ }^{39}$ George V. Mann et al., "Diet and Cardiovascular Disease in the Framingham Study. I. Measurement of Dietary Intake," Am. J. Clin. Nutr. 11 (September 1962):200.

${ }^{40}$ E. H. Ahrens and Charles A. Boucher, "The Composition of a Simulated American Diet," J.Am. Diet. Assoc. 73 (December 1978):613.

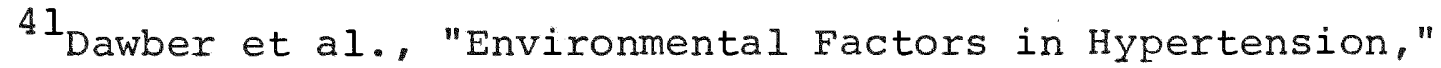
p. 255 .

${ }^{42}$ SCOGS, Evaluation of Health Aspects of Sodium Chloride, p. 8 .

43 Olaf Mickelson et al., "Sodium and Potassium Intake and Excretions of Normal Men Consuming Sodium Chloride or a 1:I Mixture of Sodium and Potassium Chlorides," Am. J. Clin. Nutr. 30 (December 1977): 2033 .

${ }^{44}$ Food and Drug Administration, Preliminary Data: FY 77, Selected Minerals in Food Survey/Total Diet Studies (Washington, D.C., Department of Health, Education and Welfare, 1977).

${ }^{45}$ Fred R. Shank, "Recent Data on Amounts of Sodium and Potassium Being Consumed and Future Considerations in Food Labeling," in Sodium and Potassium in Food and Drugs, eds. D. L. White and S. C. Croco (Chicago: American Medical Association, 1980), p. 23. p. 4 .

${ }^{46}$ SCOGS, Evaluation of Health Aspects of Sodium Chloride, 
47 Bowen et al., "Designing Food," p. 366.

48 Robert $W$. Tuthill and Edward J. Calabrese, "Drinking Water Sodium and Blood Pressure in Children: A Second Look," A.J.P.H. 71 (July 1981): 722 .

${ }^{49}$ scogs, Evaluation of Health Aspects of Sodium Chloride, p. 12 . p. 79 .

${ }^{50}$ Fregly, "Estimates of Sodium and Potassium Intake,"

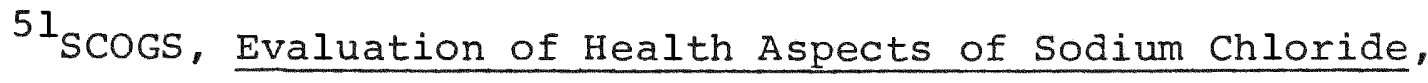
p. 11 .

${ }^{52}$ F.D.A., Selected Minerals Survey.

${ }^{53}$ Shank, "Recent Data on Sodium," p. 29.

${ }^{54}$ SCOGS, Evaluation of Health Aspects of Sodium Chloride, p. 9 .

${ }^{55}$ Dickonson, "Salt Sources and Markets," p. 49.

${ }^{56}$ Fregly, "Estimates of Soäium and Potassium Intake," p. 794 .

${ }^{57}$ Carroll S. Abraham, Fats, Cholesterol, and Sodium Intake in the Diet of Person 1-74 Years: United States. Advance Data No. 54 (Washington, D.C.: Department of Health, Education, and Welfare, 1979).

${ }^{58}$ Horace Schwerin et al., "Food Eating Patterns and Health: A Re-examination of the Ten-State and Hanes I Surveys" Am. J. Clin. Nutr. 34 (April 1981):568.

${ }^{59}$ Food and Drug Administration, Selected Minerals in Food Survey.

${ }^{60}$ Shank, "Recent Data on Sodium," p. 23.

${ }^{6 l_{\text {Fregly, }}}$ "Estimates of Sodium Potassium Intake," p. 796.

${ }^{62}$ SCOGS, Evaluation of Health Aspects of Sodium Chloride, p. 36 . p. 735 .

${ }^{63}$ Laragh and Pecker, "Dietary Sodium; Some Myths,"

${ }^{64}$ National Research Council, Food and Nutrition Board, Towards Healthful Diets (Washington, D.C.: National Academy of Sciences, 1980). 
${ }^{65}$ U.S. Department. of Agriculture, Department of Health, Education and Welfare, Nutrition and Your Health: Dietary Guidelines for Americans (Washington, D.C.: U.S. Government Printing Office, 1980).

${ }^{66}$ L. J. Filer, Jr., "Availability of Suitable Foods in the Market Place. Are Suitable Low-Salt Foods Available in the Market," in Childhood Prevention and Atherosclerosis and Hypertension, eds. R.M. Lauer and. R.B. Shekelle (New York: Raven Press, 1980), p. 411 .

${ }^{67}$ Erica F. Wheeler, "Food Choice and U.S. Dietary Goals," J. Hum. Nutr. 32 (1978):325.

${ }^{68}$ U.S. Department of Agriculture, Dietary Guidelines

${ }^{69}$ Lecos, "Tips for Consumer," p. 27.

70 "C.S.P.I. Says Salt Estimate Faulty," C.N.I. Weekly Report 12 (February 1982): 7 .

${ }^{71}$ Shank et al., "Perspective of F.D.A.," p. 32 .

72 Hunt, "Sodium Intake and Hypertension," p. 727.

73 "A Current Prospective on the sodium Issue," Nutrition Policy Issues 10 (April 1982): 1 . 
CHAPTER III

CONDUCT OF THE STUDY

\section{STUDY OBJECTIVES}

The present study was conducted to determine the feasibility of a technique to estimate discretionary salt consumption by airline passengers. The study was designed to achieve the following objectives:

1. Determine feasibility of estimation of salt use in inflight food service by observation of returned airline food trays.

2. Determine usual salting practices during inflight meal service (coach).

3. Determine possible differences in use of discretionary salt by airline passengers that select different menus; and that fly on different days.

4. Determine sodium content of airline meals.

\section{THE SETTING}

The study was conducted between January and March 1983 at an inflight meal service facility located at a South Florida airport. The facility prepares meal trays for major airline flights, both domestic and international. The meals are prepared by a full kitchen food service staff, 
with the exception of three catered food items. The meal trays from incoming flights are received directly from the flight terminal in thirty-six tier metal tray carriers. The food and refuse on the trays are discarded and trays are sanitized.

\section{DESCRIPTION OF SUBJECTS}

The subjects consisted of a population of airline coach passengers traveling on direct flights from Los Angeles to Miami. There was no control of ages, sex, occupations, ethnicity, income, or social levels. At the time the study was conducted, a $\$ 99$ fare special was being offered. Therefore, the passenger population may have included a wider range of income levels than normal.

The survey was conducted two consecutive nights weekly (one week night and one weekend night) for eight weeks. The passenger count of the study survey ranged from eighty-one to 175 per flight, with an average flight count of 128. A total of 1027 passengers were surveyed. The menu composition for each of the eight dinner flights was as follows: Flights one through four offered a choice of either roast beef which was chosen by $60 \%$ of the passengers, or stuffed shell florentine which was chosen by $40 \%$ of the passengers. Flights five through eight offered a choice of either roast veal which was chosen by 50 to $77 \%$ of the passengers or ravioli which was chosen by 23 to $50 \%$ of the passengers (See Table 2). 


\section{CYCLE I MENU}

DATE

$2 / 17 / 83$

$2 / 18 / 83$

$2 / 24 / 83$

$2 / 25 / 83$

$3 / 03 / 83$

$3 / 04 / 83$

$3 / 10 / 83$

$3 / 11 / 83$

ROAST BEEF $(8)$

58

63

59

57
STUFFED SHELI FLORENTINE $(q)$

42

37

41

43

\section{CYCLE II MENU \\ VEAL LASAGNA COMBO (o}

66

49

77

72
RAVIOLI $(8)$

34

51

23

28

The sodium content of menus varied and ranged from 1.675 to 2.185 grams of sodium per meal, with an average of 1.948 grams per meal. (See Appendix E)

\section{COLLECTION OF DATA}

Prior to the study, representative salt packets of the type included in the passenger's "tray pack" were weighed to the nearest one-hundredth of a gram, utilizing an electronic digital gram scale. A sampling of ten full packets were weighed. The full weight ranged from 1.18 to 1.28 grams, with the mean full weight of 1.23 grams. (See Table 3) 


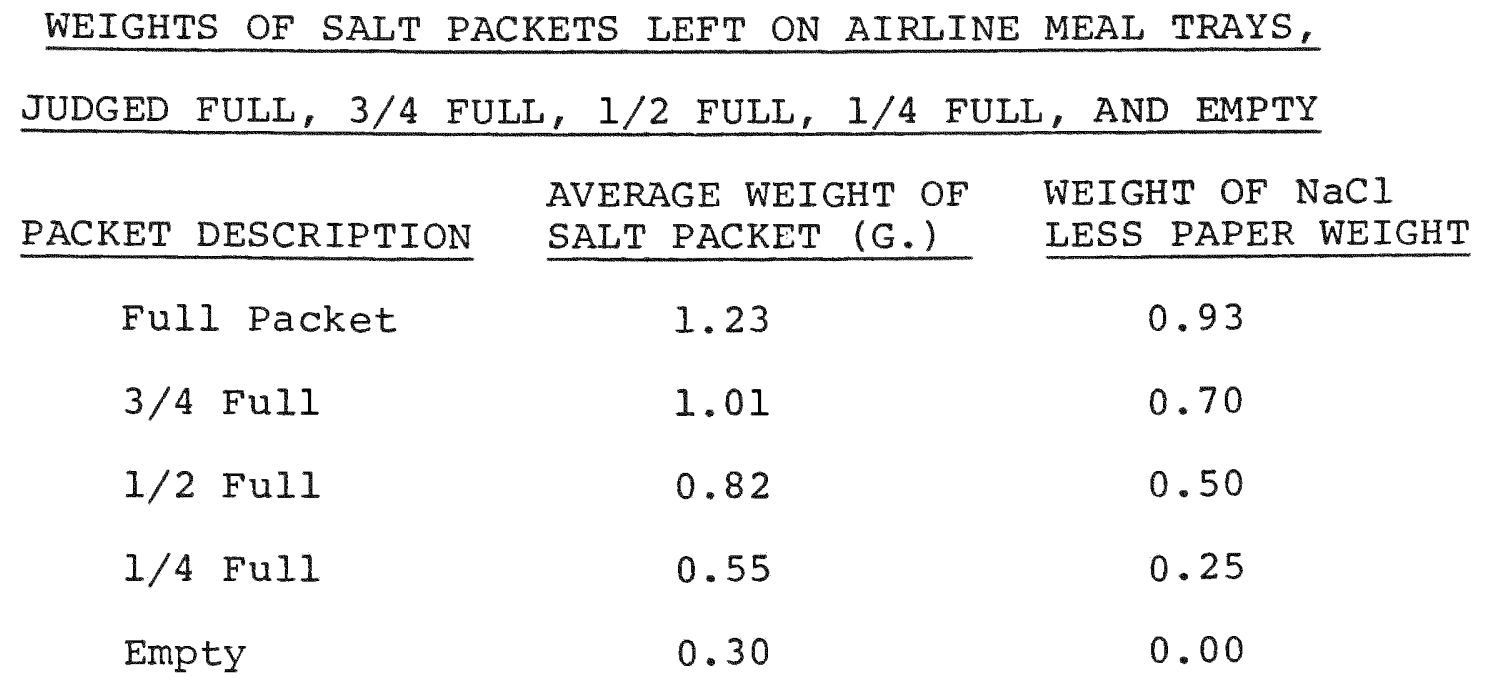

The data was collected by the same person (the author) throughout the entire experimental period. Food service personnel and shift supervisors were informed of the study protocol to assure that the entire number of tray carriers were delivered intact to the food disposal area directly from the chosen flight.

The data collector arrived at the in-flight service meal facility 30 minutes after the scheduled arrival of the study flights. Study flights were all direct Los AngelesMiami service arriving at $8: 30 \mathrm{p} . \mathrm{m}$. daily. The collector observed all returned meal trays from each study flight.

Flight date and menu were recorded for returned meal trays on talley sheets. The salt packets were collected man- 
ually. As each packet was collected, the estimated weight or portion unused was visually observed and recorded. The salt packet estimated weight was marked on the actual packet, which was then taped and dated. The salt packets were then weighed on a gram scale. Other recordings included amount of entree and salad consumed. "Unusual" trays were noted, such as special therapeutic diet trays or two or more entrees or salads on a tray. The talley sheets from each flight were totaled at the completion of the three month period for purposes of data analysis. (See Appendix A)

A trial data collection had been conducted for six weeks from January to February, 1983. Although data will not be reported, this trial collection helped to develop the data collection routine. The passenger count for a trial survey ranged from 105 to 258 per flight, with an average count of 207. A total of 1,037 were surveyed.

Samples of all food items offered in flight were collected and sodium assays were performed on each. The laboratory analysis of the actual food served was then compared to sodium content of estimates for those items drawn from standard tables. (See Table 4) 
ENTREE

Roast Beef

Ravioli

Stuffed Shell

Florentine

Veal Lasagna

Combo
VALUE CALCULATED FROM PENNINGTON

LAB ASSAY

$(\mathrm{mg})$

792

$1030-1112$

1090

982
887

19

829

960

\begin{tabular}{c} 
AND CHURCH \\
$(\mathrm{mg})$ \\
\hline
\end{tabular}

700

16
PERCENTAGE DIFFERENCE

$7-14$

\section{DATA ANALYSIS}

The data from eight airline dinner flights were handtallied by the data collector. The salt packets were weighed and grouped into usage categories according to the amount of salt remaining in the packets. The central tendency (mean), variability (range), and percentage of the total number of packets collected were computed for each category. The standard deviation was determined for each mean score. These computations were also determined for estimated discretionary salt consumption according to flight and menu.

Laboratory assays of the sodium content of the food items was performed by the author at Florida International University Food Chemistry Laboratory. (See Appendix B) 
The following procedure was used: A mortared two-gram meal sample of each menu entree with accompaniments (this did not include processed food items; cheese, bread, butter, and beverage), was diluted with .5 milliliter of $\mathrm{K}_{2} \mathrm{CrO}_{4}$. The sample was then titrated with . I normal $\mathrm{AgNO}_{3}$ to determine the precent $\mathrm{NaCl}$ content (grams NaCl/100 milliliter sample).

Sodium assays were expressed as the amount of sodium (milligrams) per 3.6 ounce portion. (See Appendix D) Assays were performed only on main dish items (entree + vegetables), since the remaining accompaniments consisted of processed foods with established sodium values (roll, cheese, crackers, butter, and salad dressing). (See Appendix E)

The sodium content of each in-flight meal was also calculated according to: 1) values from Pennington and Church, ${ }^{1}$ 2) standardized recipes for the airline prepared foods, and 3) nutrition information from food processing companies for catered food items. (See Appendix E)

The $F$ value calculated from the one-way analysis of variance statistical test was used to determine the significance of the difference between the means for table salt consumed by groups of passengers on different flights, consuming different menus, and consuming different portions of salad and entree at a meal. The criteria for accepting statistical significance of the "F score" was set at $p<.01$ level for this study. ${ }^{2}$ 
${ }^{1}$ Jean A.J. Pennington and Helen N. Church, Bowes and Church's Food Values of Portions Commonly Used. 13th Edition. (New York: Harper and Row, 1980).

${ }^{2}$ Vicki.F. Sharpe, Statistics for the Social Sciences (Boston: Little, Brown, and Company, 1979), pp. 92-95. 
CHAPTER IV

RESULTS AND DISCUSSION

\section{DATA RESULTS AND ANALYSIS}

The range and average weights of salt packets were determined for each of five categories. (See Table 3) The empty packets containing no table salt weighed from .29 to .33 grams, with an average weight of .30 grams. The full packet weight ranged from 1.18 to 1.28 grams, with the average weight of 1.23 grams $(.93 \mathrm{~g} \mathrm{NaCl})$. The threequarter full packet weight ranged from .95 to 1.10 grams, with the average weight of 1.01 grams $(.70 \mathrm{~g} \mathrm{NaCl})$. The half full packet weight ranged from .76 to .88 grams, with the average weight of .82 grams $(.50 \mathrm{~g} \mathrm{NaCl})$. The onequarter full packet ranged from .47 to .63 grams, with the average weight to be .55 grams, $(.25 \mathrm{~g} \mathrm{NaCl})$. Thus, it appears that the average salt packet does contain approximately one gram of salt.

Table salt usage for the total airline passenger population was expressed as the percentage of passengers in each usage category (See Table 5). Sixty-three percent of the passengers did not use the salt packet $(0.0 \mathrm{~g})$; six percent used the entire packet $(.93 \mathrm{~g})$; five percent used three quarters of the packet $(.70 \mathrm{~g})$; seven percent used half 


\section{TABLE 5}

\section{AIRLINE PASSENGERS IN EACH DEFINED CATEGORY}

\section{OF TABLE SALT USE}

SALT USE CATEGORY

No salt used

(full packet left on tray)

$1 / 4$ packet used

$1 / 2$ packet used

$3 / 4$ packet used

Complete packet used

No evidence of packet on tray
NUMBER OF

PASSENGERS
PERCENT OF

PASSENGERS
651

76

70

52

64

114
11

63

8

7

5

6 
of the packet $(.50 \mathrm{~g})$, and eight percent used one-quarter of the packet $(.25 \mathrm{~g})$ on the tray. Eleven percent of passengers returned trays with no evidence of a salt packet. Thus at least 26 percent of airline passengers consuming inflight meals salt their food.

Table salt usage by the airline passengers per flight was estimated and averages were computed (See Table 6). Table salt consumption ranged from .9 grams to .21 grams per meal. The average table salt usage for the entire airline passenger population was .17 grams \pm .30 per meal. There was no significant difference in table salt consumption among flights.

Table salt usage according to entree consumed was estimated. Average consumption figures and standard deviations were computed. (See Table 7) Considering the total passenger population (those who added salt and those who did not), the average amount of table salt consumed for menu $A$ was .18 grams \pm .33 for menu $B, .15 \pm .29$ for menu $C, .19 \pm .31$ and for menu $D, .16 \pm .29$ Estimations of table salt usage according to entree was also expressed as percent of passenger population in each usage category. (See Figure 1) As can be seen, there was no significant difference in table salt consumption between the different entrees. An average of 11 percent of the passengers from each menu category left no evidence of a salt packet on the tray. 
TABLE 6

AVERAGE TABLE SALT USED ON DIFFERENT FLIGHT DATES

AVERAGE GRAMS

FLIGHT DATES

DISCRETIONARY NaCI USED

$2 / 17 / 83$

.20

$2 / 18 / 83$

.17

$2 / 24 / 83$

.16

$2 / 25 / 83$

.21

$3 / 3 / 83$

.10

$3 / 4 / 83$

.15

$3 / 10 / 83$

.21

$3 / 11 / 83$

.15

Analysis of variance gave $F=1.58$

No significant difference in salt used between flights, 
TABLE 7

AVERAGED TABLE SALT USE BY AIRLINE PASSENGERS

WHO SELECTED DIFFERENT ENTREES

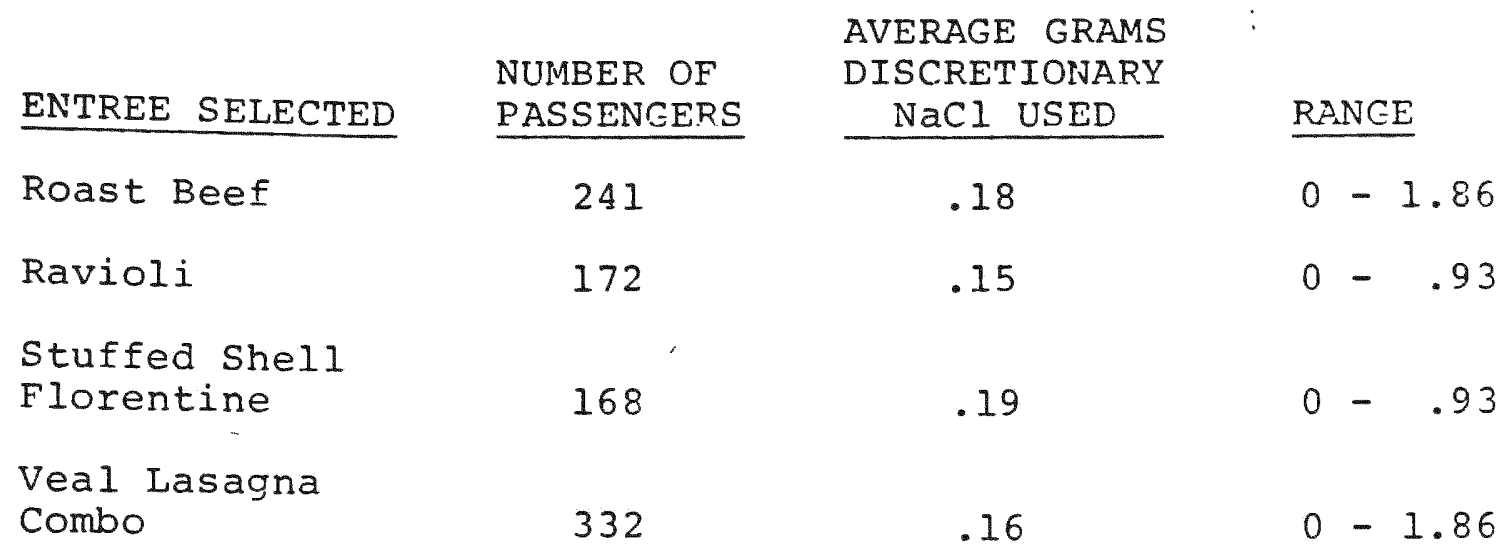

Analysis of variance: $F=.75$;

No significant difference in salt use among passengers choosing different entrees. 


\section{COMPARISON OF TABLE SALT USE BY AIRLINE PASSENGERS}

SELECTING DIFFERENT MEAL ENTREES

'assengers if

'assengers

mount of lacl Used

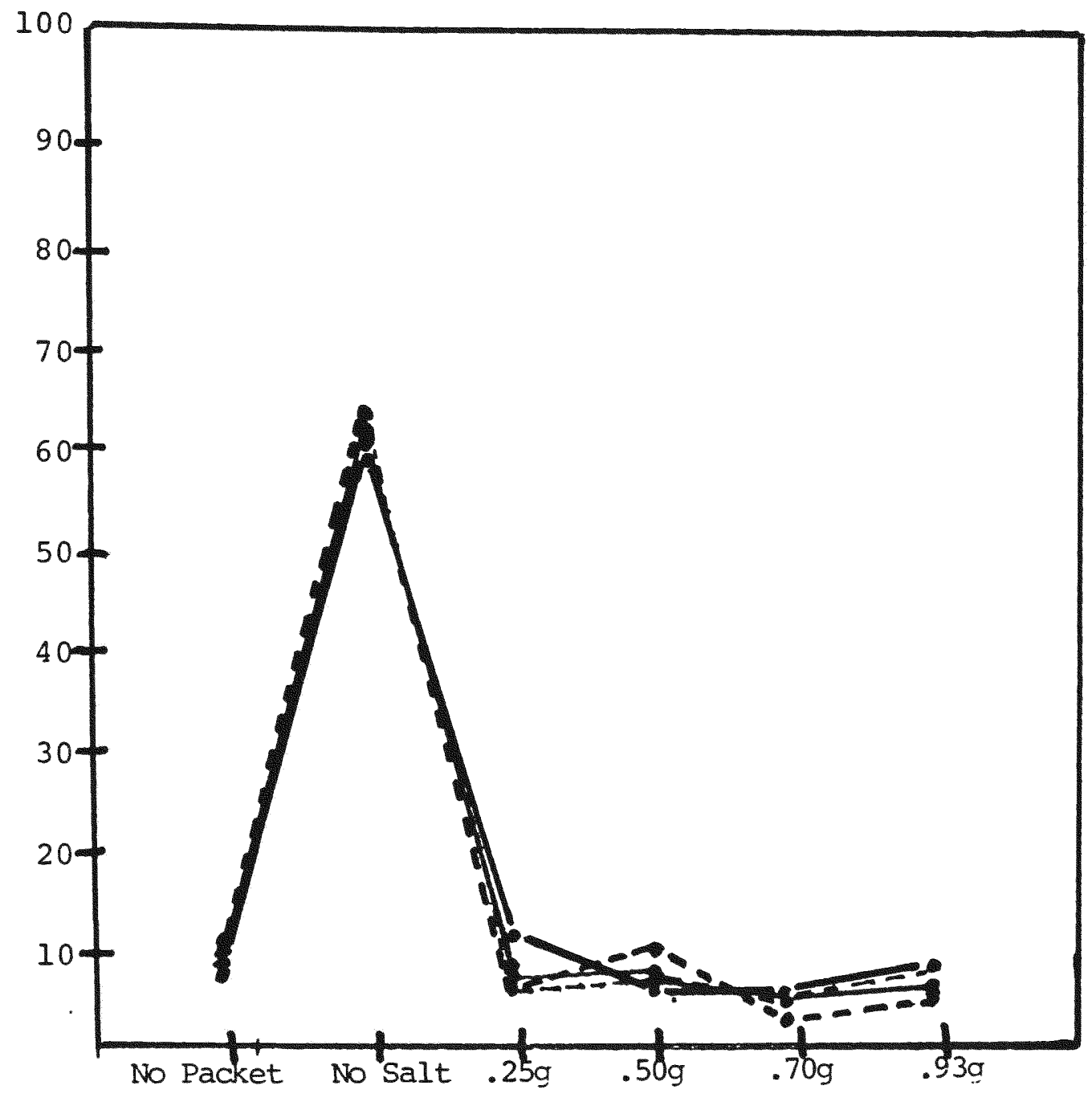

Menu Choice:
A - Roast Beef
B - Ravioli
C - Stuffed Shell Florentine
D - Veal Lasagna Combo 
Among passengers who did use salt packets, the average amount of table salt consumed for menu A was .57 grams \pm .35 for menu B .59 grams \pm .25 ; for menu $C \cdot .60$ grams \pm .24 ; and for menu $D .53$ grams \pm .28 . For all menus the average salt use, among those who did use salt packets was . $583 \mathrm{~g} \cdot \pm .287$.

The average table salt consumption was calculated according to amount of salad/entree consumed. (See Table 8) Results showed that for plates with no salad and part of entree consumed, the average table salt consumed was .07 grams. For those plates with both salad and entree consumed, the average table salt consumed was .19 grams. It can be seen that as more food was consumed, more table salt was used by the passenger.

The one-way analysis of variance was calculated to determine the significance of the difference between table salt consumption figures according to entree. The F value of .75 (Table 7) among the four entrees was not statistically significant ( $p .01)$.

One-way analysis of variance was calculated to determine the significance of the difference in table salt consumption according to amount of salad/entree consumed. The $F$ value of 3.46 was statistically significant (p.01). It was observed that one category (A/A - all salad consumed / all entree consumed) 
TABLE 8

AVERAGE TABLE SALT USED BY AIRLINE PASSENGERS

CONSUMING DIFFERENT AMOUNTS OF ENTREE AND SALAD

NUMBER OF

PASSENGERS

2

72

62

70

115

107

472
AMOUNT OF ENTREE CONSUMED

None

Part

Part

Part

Al1

AlI

All
AMOUNT OF

SALAD CONSUMED

Part

None

Part

AlI

None

Part

A11
AVERAGE GRAMS $\mathrm{NaCl}$

.35

.07

.11

.14

.14

.22

.19

Analysis of variance: $F=3.46$ Significant difference in salt use between passengers consuming different amounts of entree and salad. 
accounted for 52 percent of all table salt consumed by the passengers: it was suspected that this was probably responsible for the statistical significance. Eliminating the $A / A$ category, the analysis was repeated. Contrary to expectation, the $F$ value of 3 . was also statistically significant $(p<.01)$.

Thus, amount of entree/salad consumed did affect salt consumption. To examine the effect of salad consumption alone, the test was repeated again, holding the amount of entree consumed constant. The $F$ value for the remaining three plates of 1.84 did not represent a significant difference $(\mathrm{p}<.01)$

\section{DISCUSSION}

Factors held constant during data collection were the following: the same flight on the same consecutive days of the week were surveyed; the composition of the meal offered was relatively consistent (standarized recipes and standard portions were utilized); the menu was limited; the in-flight service staff working with the meal trays were relatively constant; and data was collected by the same person during the entire experimental period.

Limitations in the experimental design could affect the accuracy of the estimated table salt consumption figures. First, the degree of uniformity of the airline passenger population could not be assessed. Second, the data collector had to estimate 
the weight or portion of sodium chloride unused, label, date, and tape each packet for subsequent actual weighings in the laboratory. During transport, the taped salt packets could lose some salt granules. Third, the time required for each collection period was lengthy, i.e., approximately four hours, and the sharpness and accuracy of the recordings toward the end of the time period could have been compromised by fatigue. The latter two sources of error could have been eliminated 1) by the use of a digital gram soale at the facility site so that packet collection and weighing could be done simultaneously and 2) by additional manpower so that one person could collect packets while a second person recorded the weight and tray observations. These time saving considerations are important for future studies.

A fourth source of potential error was that approximately 11 percent of those passengers surveyed left no evidence of a salt packet on the tray or left two or more packets on one tray. This source of error could be reduced if flight personnel were informed of the study protocol and trained accordingly. For example, they could assure proper disposal of trays into the carrier to eliminate disarray and stacking of two or more entrees on the tray. Also, the personnel could be asked to leave all refuse on the tray and not dispose of refuse into "waste bags." This would help assure most trays showing evidence of a salt packet. 
A limitation of the data collection technique for extrapolation of results to the general American public was that the survey was limited to those persons who could afford to travel by air: Lower middle to high economic class. Even though the airline passengex population surveyed probably did encompass a wider income range than usual due to the special $\$ 99$ fare offered during this time peroid, the low income population was still eliminated in the survey. The possibility exists that the low income population may have different salting practices than other segments of the population. This is an important concern since there is a higher incidence of hypertension in the lower economic bracket. 1

Despite the limitations of the technique, the monitoring of table salt usage on airlines could be useful, especially if combined with an assessment of nutritional knowledge of the air passenger population. It might be used to predict, with reasonable accuracy, the effects of different types of intervention, such as informative inserts about salt use in airline magazines. The technique could also be used to determine the salt sensitivity of the airline passenger population, if entrees containing widely differing amounts of $\mathrm{NaCl}$ were presented.

The table salt consumption figures were compared to the estimated discretionary salt intake figures from previous studies (See Table 9): the $1968-70$ retail sales survey 


\section{COMPARISON OF DISCRETIONARY SALT CONSUMPTION}

\section{FIGURES WITH OTHER STUDIES*}

STUDY

1966-70 Bureau of Mines Data (Bowen)

1977

$1977-80$

1976

$1968-70$

1983
Dietary Survey (Mickelson)

F.D.A. Total Diet Studies

F.D.A. Total Diet Studies

Retail Sales Survey (Wood)

Survey (Dierkes)
AVERAGE CONSUMPTION $\mathrm{NaCl}$ PER DAY/(g)

6.5

5.5

4.7

4.5

3.4

2.4

TABLE 9B

COMPARISON OF TABLE SALT CONSUMPTION FIGURE

WITH DIETARY SURVEY

STUDY

1977

1983
Dietary Survey (Mickelson)

Survey (Dierkes)
AVERAGE CONSUMPTION NaCI PER DAY $(g)$

3.2

.50

*Discretionary salt denoted here includes both salt used in cooking and salt used at the table 
(Wood), the 1965 U.S.D.A. survey, the 1966-70 Bureau of Mines survey (Bowen), the 1972-1980 F.D.T. total diet studies, and the 1977 dietary survey (Mickelson). For comparison, data from this sudy were extrapolated, speculating that the salt levels in the study meals are not unusual and that salting practices in flight is typical of the passengers' usual behavior. The amount of salt used on the airline meal was multiplied by three meals per day. If used at all meals the levels of salt usage in this study would represent a decrease in discretionary salt use fram the usage reported in previous studies. An optimistic conclusion is that this study may provide the first glimpse of a $t$. end toward decreased discretionary salt use since the advent of the Dietary Goals.

However, since the previous reported study estimates were from four to fourteen fold greater than the airline estimates, reason for difference must be sought. The difference in estimated table salt consumption could be due to a number of factors: First, many passengers who normally salt their food at home may not do so on an airline meal, due to high salt content of airline food. For example, one of the two entrees offered at each meal was an italian dish that is highly seasoned. Second, public perception that airline food is "processed," may lead some passengers to abandon their usual salting practices. Third, as mentioned before, the survey is not representative of the entire population and there is the possiblity that the omitted low income group may, perhaps, practice heavier salting than others. 
Two possible predictors of salt use were investigated in this study: The sodium content of the meal and inclusion of a salad with the meal. (See Tables $4,7,8$ ) It was found that table salt intake figures did not differ significantly among the menu choices; thus, it can be inferred that the airline passenger is not influenced by the sodium content of the meal and appears to salt the food without discretion. The table salt intake figures did not differ significantly according to the absence/presence of a salad with the meal. However, it was observed that the amount of the entree left on the tray (anount consumed) influenced salting practice. It appeared that the amount of entree consumed (on any menu) influenced the amount of table salt used by the passenger, without respect to the sodium content of the meal.

The sodium estimates of the inflight meals derived from the laboratory assays and from standard references differed by approximately 100 milligrams. (See Table 4, Appendix E) The variation between the sodium estimates could be due to a number of factors. First, the values reported in a standard reference do not always reflect the sodium content of homemade items due to variability in the use of salt as a seasoning by the cook. Specifically, the sodium content of entrees in this study were expected to vary from meal to meal due to utilization of standaraized recipes which call for "salt to taste" (veal roast, pot roast of beef, and mushrooms in cream sauce). 
Second, the laboratory procedure is dependent on the experimentor's perception of a color change. (See Appendix C) In this experiment, the experimentor looked for a brown color change. Perhaps a delayed response to the immediate color change could be responsible for the higher sodium values. Whatever the source of error, it can be seen that the sodium content per menu was similar using both techniques of estimation. For example, both techniques estimated the sodium content of roast beef as the lowest value of the various entrees. Thus, "book estimates" are useful for obtaining a "ball-park figure" for ranking entrees by their sodium content. 


\section{REFERENCES}

p. ${ }^{\text {I }}$ Schewerin et al., "Food Eating Patterns and Health," 
CHAPTER V

SUMMARY, CONCLUSIONS, AND RECOMMENDATIONS

\section{SUMMARY}

Review of the literature revealed that there is awareness, by the food industry and by the consumer, of potential harmful effects of chronic excess sodium chloride consumption. It also revealed that the food industry is decreasing the amount of salt in processed foods available on the market today.

The study investigated the feasibility and limitations of a data collection technique used to assess discretionary salt intake in in-flight meal service. Discussion of the limitations of the technique, such as lack of control of subjects, exclusion of low income population, and limited menu selection was offered.

Flight day, sodium content of the inflight meal, and salad consumption at the meal were found not to influence salting habits of passengers as measured by the study technique. Amount of entree consumed did influence the amount of salt added to the meal.

Extrapolating inflight salting practice to estimate an habitual level of salt use revealed a lower level of use than would be predicted from other types of studies. 
Reliability of laboratory assay of sodium content of the airline meal was discussed.

\section{CONCLUSIONS}

The study results suggest that sodium content of an inflight meal does not influence discretionary salting practice; rather, it appeared to be dictated by habitual practice of the passenger. Also, the study results showed that the inclusion of a salad at the meal did not affect the airline passenger's salting practices.

The data collection technique employed in the study seemed a feasible method for collecting discretionary salt intake data and could be useful in future studies to determine effectiveness of consumer education/media techniques. However the data collection technique will not provide accurate estimates of discretionary salt intake of the American public in general.

\section{RECOMMENDATIONS}

The data collection techniques used in this study might be used to monitor changes in salting practices by airline passengers and to test effectiveness of consumer education techniques. For example, consumer information on sodium could be placed in an insert in the airline magazines, on a place card on the meal tray, or on the placemat itself. Salting practices could be monitored to detect changes due to this educational intervention. 
Also, the collection technique could be useful for investigating other factors influencing discretionary salt use by the passengers. For example, the technique could be applied when lower sodium entrees (traditional continental versus italian cuisine) are used or when one low sodium entree is included among menu choices to determine if the sodium content/knowledge of sodium content of the meal influences the airline passenger's salting practice. A re-survey when continental cuisine is offered should be conducted to test reliability of the results from this study. 
APPENDIX 
Date:

\begin{tabular}{l} 
SALT IN PACKET \\
No $\mid 1.0$ \\
\hline
\end{tabular}


SUPPLIES: $\quad 100 \mathrm{ml}$. Beakers

$250 \mathrm{ml}$. Flasks

Funnels

\#4 Filter Paper

2 Biurets

$\mathrm{K}_{2} \mathrm{CrO}_{4}$

. $1 \mathrm{~N} \mathrm{AgNO}_{3}$

Dionized water

Food Processor

PROCEDURE: 1. Blenderize sample.

2. Weigh 2 gram sample in beaker, mix with 20 ml, hot water.

3. Filter into flask. Wash beaker into filter with additional $10 \mathrm{ml}$. hot water.

4. Add . $5 \mathrm{ml} . \mathrm{K}_{2} \mathrm{CrO}_{4}$ to flask.

5. Titrate with. IN $\mathrm{AgNO}_{3}$ until color turns brown.

6. Formula for percent sodium chloride:

$\%$ (grams $\mathrm{NaCl} / 100$ grams) $=\frac{\mathrm{ml} .1 \mathrm{~N} \mathrm{AgNO}}{\mathrm{Wt} \text {. Sample }(2 \mathrm{~g})}$ 
Menu Item

Stuffed Shell Florentine

Salad

Ravioli

Veal Lasagna Combo

Roast Beef

Peach Tart

Strawberry Tart

Salad Dressing

Test $=1 \mathrm{NaCl} / 100 \mathrm{ml} \cdot \mathrm{H}_{2} \mathrm{O}$

$\% \mathrm{NaCl}=\frac{\mathrm{ml} \cdot .1 \mathrm{AgNO}_{3} \mathrm{x} .585}{\mathrm{wt} \cdot \text { Sample }}$

* $\mathrm{J}=\mathrm{Juiced}$

$\mathrm{P}=$ Pureed

\section{Form}

$\mathrm{J}$

$\mathrm{J}$

$\mathrm{J}$

$\mathrm{J}$
$\mathrm{P}$

$\mathrm{P}$
$\mathrm{P}$

$\mathrm{P}$
$\mathrm{P}$

$P$

$\mathrm{P}$

$\mathrm{J}$ wt. Beaker + 29. Sample

43.13

42.63

49.79

52.10

45.36

44.53

44.06

45.99

44.17

44.10

42.62

42.62

46.03

46.03

49.66

49.66
Ml. AgNo

To Achieve

Color Change

$$
7.50-11.25=3.75
$$

$11.25-15.00=3.75$

$17.25-19 \cdot 25=2.00$ $15.00-17.25=2.25$

$19.25-22.25=3.00$ $26.50-29 \cdot 75=3.25$

$37.75-40 \cdot 50=2.75$ $40.50-43.25=2.75$

$43.25-45.75=2.5$ $45.00-47.50=2.5$

$21.00-21.50=.5$ $21.50-22.0=.5$

$20.00-21.00=.5$ $20.00-22.50=.5$

$47.00-52.0=5.0$ $52.00-57.0$

$5.75-25.75=20.0$ complete color change 


\section{BY LABORATORY ASSAY}

LABORATORY ANALYSIS:

Meal Sample

(1) Stuffed Shell Florentine \#1

2

(2) Salad

(3) Ravioli

(4) Veal Lasagna Combo

(5) Roast Beef

(6) Peach Tart

(7) Strawberry Tart

(8) Salad Dressing g. NaCl/l00g Sample From 3.6 Portion $\mathrm{Na}(\mathrm{g})$

.436

.436

.236

.264

.352

.380

.320

.320

.292

.292

.060

.060

.060

.060

.584

.584 
MENU

(1) Menu A

$3 \mathrm{oz}$. Roast beef with sauce

1 oz. Carrots and peas

2.5 oz. Stuffed baked potato

$1.5 \mathrm{oz}$. Broccoli spears in butter Market salad

Herb dressing

Hard roll

Butter cup

Peach tart

Cheese

Crackers

(2) Menu B

$7 \mathrm{oz}$. Ravioli Bolognaise

$1.5 \mathrm{oz}$. Scandanavian buttered vegetables

$1.75 \mathrm{oz}$ Broiled tomato half

Alfalfa salad

Herb dressing

Hard roll

Butter cup

Strawberry tart

Cheese

Crackers
CALCULATED Na VALUE*

$\mathrm{Na}(\mathrm{mg})$

154.

74.

175.08

297.20

135.95

$366 .-439.5$

219

50 .

142.75

62. -177 .

$100 . \quad-176$.

$1 \frac{100.78-1970.28 \text { Total }}{1675.70}$

$\mathrm{Na}$ (mg)

490.5

71.

398.83

20 .

366. -439.5

219 .

50.

142.75

62.

$\frac{100 \quad-176 .}{1920.05-2184} .55$ Total 
(3)

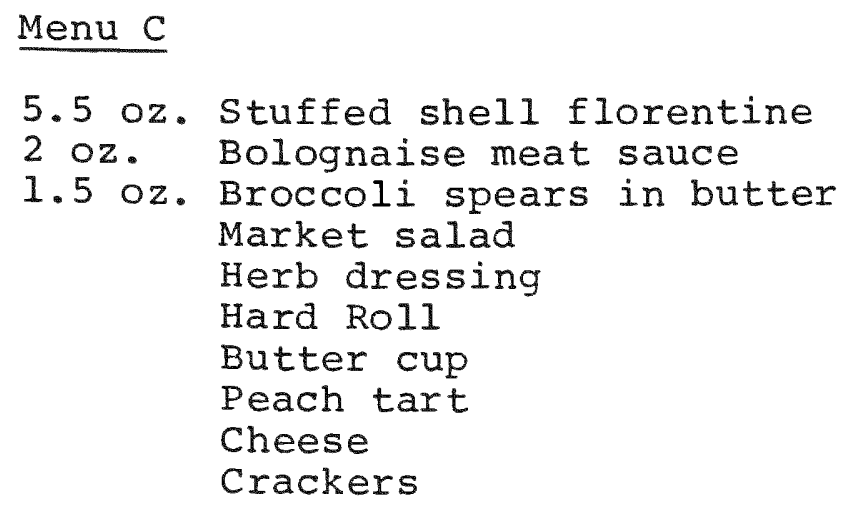

Menu C

$5.5 \mathrm{oz}$. Stuffed shell florentine

$2 \mathrm{oz}$. Bolognaise meat sauce

$1.5 \mathrm{oz}$. Broccoli spears in butter

Market salad

Herb dressing

Hard Roll

Butter cup

Peach tart

Cheese

Crackers

(4) Menu D

$3 \mathrm{oz}$. Veal roast in mushroom cream sauce $(1.5 \mathrm{oz}$.

$3 \mathrm{oz}$. Vegetable lasagna

$1.5 \mathrm{oz}$. Scandanavian butter vegetables

$1.75 \mathrm{oz}$ Broiled tomato half

Alfalfa salad

Herb dressing

Hard Roll

Butter cup

Strawberry tart

Cheese

Crackers
Na (mg)

478.17

111.8

297.2

135.95

366. -439.5

219 .

50 .

142.75

62. - 177 .

100. -176.

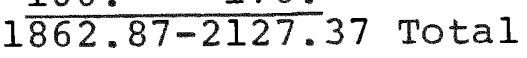

$\mathrm{Na}(\mathrm{mg})$

173.25

186.38

71.

398.83

20 .

366. -439.5

219 .

50 .

142.75

62. - 177 .

$\frac{100 .-176 .}{1809.21-2073.71 \text { Total }}$

*Calculated from Pennington and Church, Marriott Inn Standardized Recipes, and Vendor Nutritional Information 


\section{BIBLIOGRAPHY}

Abraham, Sidney and Carroll, Margaret. Fats, Cholesterol and Sodium Intake in the Diet of Persons, 1-7 Years: United States. Advance Data No. 54. Washington, D.C.: Department of Health and Human Services, December 17, 1979.

"A Current Prospective on the Sodium Issue." Nutrition Policy Issues 10 (April 1982): 1-2.

Ahrens, E. H. and Boucher, Charles A. "The Composition of a Simulated American Diet." J.Am. Diet. Assoc. 73 (December 1978): 613-620.

Allen, F. M. Treatment of Kidney Disorders and High Blood Pressure. Morriston, New Jersey: The Physiatric Institute, 1925.

Ambard, L. and Beaujard, E. "Causes de L'Hypertension Arterielle." Arch, Gen. Med. 1 (1904): 520-530.

American Academy of Pediatrics Committee on Nutrition "Salt Intake and Eating Patterns of Infants and Children in Relation to Blod Pressure." Pediatrics 53 (January 1974): 115-121.

Beauchamp, Gary K., Bertino, Mary, and Engelman, Karl. "Modification of Salt Taste." Ann. Intern. Med. 98 (May 1983): 763-769.

Bowen, R. E., Reid, E. J., and Moshy, R. J. "Designing Formulated Food for the Cardiac Concerned." Prev. Med. 2 (1973): 366-377.

Compton, Norma H. and Hall, Alice A. Foundations of Home Economics Research. Minneapolis: Burgess Publishers, 1972 .

"CSPI Says Salt Estimate Faulty." CNI Weekly Report 12 (February 1982): 7 .

Dahl, Lewis K. "Possible Role of Chronic Excess Salt Consumption in the Pathogenesis of Essential Hypertension." Am. J. Cardiol. 8 (October 1961): 571-575.

Dahl, Lewis K. "Salt and Hypertension." Am. J. Clin. Nutr. 25 (February 1972): 231-244. 
Dahl, Lewis K. and Love, R. A. "Etiological Role of Sodium Chloride Intake in Essential Hypertension in Humans." J.A.M.A. 164 (1957): 397-400.

Darby, William J. "Why Salt: How Much?" Journal of Dentistry for Children. (September-October 1981): $372-375$.

Dawber, Thomas R., Kannel, W. B., Kagan, A., Donabedian, R. K., McNamara, P. M. and Pearson, G. "Environmental Factors in Hypertension." In The Epidemeology of Hypertension, pp: 255-283. Edited by Jeremiah Stamler, Rose stamler, and Theodore N. Pullman. New York: Grune and Stratton, 1967.

Dickonson, William E. "Salt Sources and Markets." In Biological and Behavioral Aspects of Salt Intake, pp. 49-52. Edited by R. Morely Karey, Melvin J. Fregly, and R. A. Bernard. New York: Academic Press, 1980.

Filer, I. J., Jr. "Availability of Suitable Foods in the Market Place. Are Suitable Low-Salt Foods Available in the Market?" In Childhood Prevention of Artherosclerosis and Hypertension, Pp. 411-417. Edited by R. M. Laner and R. B. Shekelle. New York: Raven Press, 1980.

Food and Drug Administration. Preliminary Data: FY 77 Selected Minerals In Food Survey/Total Diet Studies. Washington, D.C.: Department of Health, Education, and Welfare, 1977.

Forsythe, Richard H. and Miller, Ralph A. "Salt in Processed Foods." In Biological and Behavioral Aspects of Salt Intake, pp. 221-228. Edited by M. R. Kare, Melvin J. Fregly, and R. A. Bernard. New York: Academic Press, 1980 .

Fregly, Melvin J. "Estimates of Sodium and Potassium Intake." Ann. Intern. Med. 98 (May 1983): 792-799.

Fries, Edward D. "Salt Volume and the Prevention of Hypertension." Circulation 53 (1976): 589-595.

Grollman, Arthur. "Metabolic Observations in Essential Hypertension." Postgrad. Med. 33 (June 1963): 532-535.

Hunt, James C. "Sodium Intake and Hypertension: A Cause for Concern." Ann. Intern. Med. 98 (May 1983): 724-728.

Institute of Food Technologists' Expert Panel on Food Safety and Nutrition and the Committee on Public Information. "Dietary Salt." Food Technology (January 1980): 85-91. 
Isaac, Stephen and Michaels, William B. Handbook in Research and Evaluation. San Diego: Edits publications, 1971.

Kolata, Gina. "Value of Low-Sodium Diets questioned." Science 216 (April 1982): 38-39.

Laragh, John H. and Pecker, Mark S. "Dietary Sodium and Essential Hypertension: Some Myths, Hopes and Truths." Ann. Intern. Med. 98 (May 1983): 735-743.

Lecos, Chris. "Tips for the Salt-Conscious Consumer." The F.D.A. Consumer. (November 1981): 27-28.

Luft, Friederich, C. "Sodium Restriction in the Treatment of Hypertension." Cardiovascular Diseases 7 (October 1981): 15-18.

Luft, Friederich, C., Weinberger, M. H., Grim, C. E., Fineberg, N. S., and Miller, J. Z. "Sodium Sensitivity in Normotensive Subjects." Ann. Intern. Med. 98 (May 1983): $758-762$.

Mann, George V., Pearson G., Gordon, T., and Dawber, T. R., "Diet and Cardiovascular Disease in the Framingham Study. I. Measurement of Dietary Intake." Am. J. CIin. Nutr. 11 (September 1962): 200-214.

Marsh, Anne C., Klippstein, Ruth N., and Kaplan, Sybil D. The Sodium Content of Your Food. Washington, D.C.: U.S. Government Printing Office, 1980.

Meneely, George R. "The Experimental Epidemiology of Sodium Chloride Toxicity in the Rat." In the Epidemiology of Hypertension, pp. 240-249. Edited by Jeremiah Stamler, Rose Stamler, and Theodore N. Pullman. New York: Grune and Stratton, 1967.

Meneely, George R. and Battarbee, Harold D. "Sodium and Potassium." Nutr. Rev. 34 (August 1976): 225-235.

Meneely, George R. and Dahl, Lewis K. "Electrolytes in Hypertension: The Effects of Sodium Chloride. The Evidence From Animal and Human Studies." Med. Clin. North. Am. $45(1961): 27-28$.

Mickelson, Olaf, Murdani, D., Gill, J. L., and Frank R. I. "Sodium and Potassium Intakes and Excretions of Normal Men Consuming Sodium Chloride or a $1: 1$ Mixture of Sodium and Potassium Chlorides." Am. J. Clin. Nutr. 30 (December 1977): 2033-2040. 
Miller, Roger W. "The Case For Moderating Sodium Salt Consumption." The F.D.A. Consumer (October 1981): 1-5.

National Research Council, Food and Nutrition Board, Towards Healthful Diets. Washington, D.C.: National. Academy of Sciences, 1980.

Pangborn, Rose Marie and Pecore, Suzanne D. "Taste Perception of Sodium Chloride in Relation to Dietary Intake of Salt. Am. J. Clin. Nutr. 35 (March 1982): 510-520.

Pennington, Jean A. and Church, Helen Nichols. Bowes and Church's Food Values of Portions Commonly Used. New York: Harper and Row Publishers, 1980.

Pleuss, Joan and Kochar, Mehendr, S. "Dietary Considerations in Hypertension." Post Grad. Med. 69 (June 1981): 34-43.

Schwerin, Horace S., Stanton, J.L., Riley, A.M., Schaefer, A. E., Leveille, G. A., Elliott, J. G., Warwick, K. M., and Brett, B. E. "Food Eating Patterns and Health: A Re-examination of the Ten State and Hanes I Surveys." Am. J. Clin. Nutr. 34 (April 1981): 568-580.

Select Committee on GRAS Substances. Evaluation of the Health Aspects of Sodium Chloride and Potassium Chloride as Food Ingredients. Bethesda, Maryland: Life Sciences Reserach Office, Federation of American Societies for Experimental Biology, 1979.

Shank, Fred K., Kang Park, Y., Harland, B. I., Vanderveen, J. E., Forbes, A. L., and Prosky, L. "Perspective of Food and Drug Administration on Dietary Sodium." J. Am. Diet. Assoc. 80 (January 1982): 29-35.

Shank, Fred R. "Recent Data on the Amounts of Sodium and Potassium Being Consumed and Future Considerations for Food Labeling." In Sodium and Potassium in Food and Drugs: $\mathrm{Na} \mathrm{K}$ Conference Proceedings, Pp. 23-32. Edited by D. L. White and S. C. Croco. Chicago: American Medical Association, 1980.

Sharp, Vicki L. Statistics for the Social Sciences. Boston: Little, Brown, and Company, 1979.

Tuthil1, Robert W. and Calabrese, Edwarä J. Sodium and Blood Pressure in Children: A.J.P.H. 71 (July 1981): 722-729.
"Drinking Water A Second Look." 
U.S. Department of Agriculture, U.S. Department of Health, Education and Welfare. Nutrition and Your Health:

Dietary Guidelines for Americans. Washington, D.C.: U.S. Government Printing Office, 1980 .

Wallis, C. "Salt: A New Villain?" Time 119 (1982): 6471 .

Wheeler, Erica F. "Food Choice and U.S. Dietary Goals," J. Hum. Nutr. 32 (1978): 325-333.

Wilbur, Joseph A. "The Role of Diet in the Treatment of High Blood Pressure." J.Am. Diet. Assoc. 80 (January 1982): 25-28.

Wood, F. O. "Percent Usage of Iodized Salt in the U.S. Geographical Differences." In Summary of a Conference: Iodine Nutriture in the United States, pp. 30-33. Edited by Food and Nutrition Board, National Research Council. Washington, D.C.: National Academy of Sciences, 1970. 
Title of Thesis:

Discretionary Use of Table salt in Airline Food Service:

A Feasibility Study

Full Name:

Kathleen Elise Dierkes

Place and Date of Birth:

Pontiac, Michigan July 30, 1954

Elementary and secondary Education:

Meadowlake Elementary School Birmingham, Michigan

Wylie E. Groves High School Birmingham, Michigan

Colleges and Universities:

Michigan State University September 1972-June 1977

B.S. Clinical Dietetics and Nutrition

Florida International University September 1981-August1983 M.S. Clinical Dietetics and Nutrition

School of Technology- Department of Dietetics and Nutrition 